\title{
Can DuPont Analysis Predict Voluntary Delisting from Stock Exchange? Ev- idence from Pakistan
}

\author{
Muhammad Nadir Hussain Khan ${ }^{* 1} \&$ Haji Suleman Ali $^{2}$ \\ ${ }^{1,2}$ COMSATS University Islamabad, Pakistan
}

\begin{abstract}
This study explores whether voluntary delisting of companies from stock exchanges can be predicted by the DuPont Model. ROE (Return on Equity), NPM (Net Profit Margin), ATO (Assets Turnover) and LM (Leverage Multiplier) of 13 voluntarily delisted firms from Karachi Stock Exchange were compared with same ratios of respective sectors for 6 years preceding the delistment year by applying t-test. Difference of means of DuPont ratios between voluntarily delisted firms and their respective sectors were not found statistically significant. Thus, ROE, NPM, ATO and LM, which are the measures of profitability, asset utilization (efficiency) and leverage respectively, are not the significant predictors of voluntary delisting decisions in Pakistan. To the best of researchers knowledge, this study is first attempt to differentiate between voluntarily delisted and listed companies on the basis of DuPont Model.

Keyword: DuPont Model, ROE, NPM, ATO, LM, Voluntary Delisting
\end{abstract}

\section{Introduction}

A stock market functions as financial intermediary as it channelizes funds from surplus units to deficit units. Businesses find registration with stock exchanges beneficial for them. There is a possibility to raise funds from a wide spectrum of investors. Equity markets can be efficient and cost effective sources of funds under tight monetary regime with higher debt costs. It also decreases companies dependence on debt markets, and thus reduces interest burden. Listed firms can attract highly skilled staff by offering them stock options and other such incentives. Listed companies receive more media and analysts coverage which adds to the value and publicity of the company. Companies can bring their abnormal leverage back into balance.

Benefits that a listed company is likely to receive by listing include relaxation in borrowing constraints, more liquidity, enhanced bargaining power with banks, and the recognition of investors (Pagano et al., 1998; Ritter, 1987). Increased access to public markets and more transparency provides companies with better bargaining power when it comes to negotiation with banks, and thus they have less borrowing problems and more diversification of sources of funds (Bharath and Dittmar, 2006; Pagano et al., 1998). Corporations raise equity either to finance their growth or to bring their leverage back into balance (Pagano et al., 1998). US survey, on the other hand, suggests that raising funds is not the only reason behind companies go-

*Corresponding author.

Email: nadir.rehan1979@gmail.com ing public, they do so to create shares that could be used in future acquisitions (Brau, 2012). Across the Atlantic, the European companies get listed for the purposes of enhancing their bargaining position with banks, leverage reduction, and the organizations that cannot achieve their purpose of rebalancing their leverage by raising equity funds decide to turn private (Bancel and Mittoo, 2009). Findings from Bancel and Mittoo (2009) also suggest that firms go public to have more recognition. Better liquidity is an extra advantage for publicly listed companies as IPOs result in ownership distribution and superior level of liquidity with very little transaction expenses (Pagano et al., 1998).

Share liquidity is a very vital factor for the decision to go public and it is more important in United Kingdom than in continental Europe (Bancel and Mittoo, 2009). High growth companies need funds to finance their growth and they are likely to benefit by listing themselves on stock exchanges because this reduces their difficulties regarding funds as they have access to low cost external financing (Bharath and Dittmar, 2006; Fischer, 2000; Pagano et al., 1998). Bharath and Dittmar (2006); Marosi and Massoud (2007); ?found that firms having more growth opportunities are more likely to stay listed in order to raise more funds to finance their growth. Bancel and Mittoo (2009) showed that chief financial officers (CFOs) of European firms believe that funds for the growth opportunities that lie before corporations are a very important consideration while deciding to go public. 
Karachi Stock Exchange was the largest and most liquid stock exchange of Pakistan until January 2016, when all the three stock exchanges of Karachi, Islamabad and Lahore were integrated into one Pakistan Stock Exchange. Pakistan was ranked third in 2014 amongst Worlds best performing marketsa third consecutive year when the Country had earned a place amongst Worlds top 10 performing markets. By the end of April 2015, 560 companies were listed on Karachi Stock Exchange with listed capital of Rs.1177.77 billion ( $\$ 11.77$ billion) with market capitalizations of Rs. 7305.81 billion ( $\$ 73.05$ billion).

While there are benefits of being listed at stock exchanges, and many companies try to get themselves listed every year around the Globe, but at the same time many listed companies get delisted from the stock exchanges as well. Delisting is mainly of two types; involuntary and voluntary (Macey et al., 2008). Involuntary delisting is when a firm does not deliberately get delisted, but is delisted either due to financial distress ( declared bankrupt by the Court of Law), or is merged into and acquired by some other company, or is delisted by the regulators for the breach of law. On the other hand, voluntary delisting is when a company requests a stock exchange to delist it and buys back its shares from general public and ceases to be a public company out of its own will. Voluntary delisting is called Going Private Transaction-GPT. Literature in corporate finance covers the decision of corporations to go public, and the opposite phenomenon is not studied in detail. Past decade witnessed upsurge in delisting around the Globe. According to the SDC (Securities Data Company), 900 companies have been delisted from US financial market since 1996. The numbers of listed companies in United States in 2012 were 14\% less than the numbers of listed companies in US in 1975. Europe has not been an exception either. In two decades from 1995 to 2005, the number of listed European companies shrank by $25 \%$.

Ever since the inception of 21st Century, as many as 211 companies had been delisted from Karachi Stock Exchange in 16 years. The number compared with 560 listed companies is huge. A list of delisted companies from 1963 onwards is available on website of the Karachi Stock Exchange (now Pakistan Stock Exchange) and for all the companies delisted since the start of 2001, reason of delisting for each company had also been mentioned. Companies had got delisted for a variety of reasons. For example, a few companies voluntarily closed their businesses, some of mutual funds were converted into open-ended mutual funds, some companies got liquidated by the orders of Court of Law, and a large number of companies were delisted for they violated the listing regulations of the Karachi Stock Exchange. However, 78 out of these 211 companies opted to delist from the Karachi Stock Exchange voluntarily and went Private after having bought their shares back.

Now, that has been the research problem for this study. What circumstances did lead them to go Private? Did they have unique characteristics (as compared to their industry peers which stayed listed) on the basis of which we can predict if a company is going to be delisted? Were they facing profitability, efficiency and capital structure issues? The study particularly focused if components of DuPont analysis can serve as a predictor for voluntary delistment of firms. DuPont Model has not been applied to differentiate between the voluntarily delisted companies and the companies that stay listed. This is unique and first of its kind study. Therefore, the research contributes to theory of corporate finance, and is of fundamental importance as predictability of voluntary delistment of firms may change investors behavior towards them. The research will open a new avenue in corporate finance and may have theoretical and practical implications for future researchers, academicians and policy makers.

\section{Theory and Hypotheses}

DuPont Model, also known as DuPont Analysis, DuPont Equation, DuPont Identity or DuPont Method, was developed and employed by DuPont Corporation in 1920s to calculate Return on Equity (ROE). ROE, calculated through net Profit divided by equity, is an important measure of a firms performance and it tells how much a firm earns or loses for its shareholders. This is Warren Buffets favorite ratio. Mr. Warren Buffet is one of the Worlds richest persons and has earned most of his wealth by investing in stocks. However, ROE alone does not tell where the performance of the firm is coming from. In order to overcome this problem, DuPont Model breaks down ROE into following parts:-

ROE $=$ Net Profit Margin $(\mathrm{NPM})$ * Assets Turnover $($ ATO $) *$ Leverage Multiplier (LM)

Net Profit Margin (NPM) is calculated through net profit divided by sales, and is a measure of operational efficiency of the firm. NPM can be increased by either charging premium prices or by controlling production as well operating costs. Companies, with distinguished product and strong brand power, charge premium prices to increase their margins, whereas companies following cost leadership strategy rely more on cost saving to offer competitive prices to their customers. Assets Turnover (ATO), calculated through sales divided by assets, is a measure of assets management and assets utilization of the firm. It points at how optimally assets are used to generate sales revenue. Firm with differentiation strategy may have lower sales than firm with cost leadership strategy, because, the 
former relies on margin and the latter on turnover. Finally, leverage multiplier (LM), calculated through assets over equity, hints at financing policy of the firm. What is debt-equity mix and what percentage of assets are financed by debt, and equity? Higher ratio represents higher leverage. Leverage acts as doubleedged sword. If a companys debt generates more returns than its cost, then ROE will increase. A return on debt lower than its cost will work the other way. Thus, leverage can have positive as well negative effects on ROE. DuPont Model tells where the ROE is coming from. It is viewed well if it comes from NPM and Assets Turnover, and poor if it comes from leverage, because high leverage increases finance cost as well as financial risk. A successful firm should at least have either of two ratios of NPM and Assets Turnover above its rivals and competitors.

How does DuPont model relate to voluntary delistment of companies from stock exchanges? It has already been established that companies enlist themselves on stock exchanges to finance their growth (Bharath and Dittmar, 2006; Marosi and Massoud, 2007; ?). Growth ultimately increases sales, size and profitability of companies. And, when more funds are raised through equity, it reduces and balances leverage. DuPont model captures these variables. A company may remain listed on stock exchange as long as its enlistment motives are achieved, and therefore has high ROE, NPM, ATO and balanced LM. Otherwise, company may find it appropriate to delist from stock exchange. Therefore, it may be expected that voluntarily delisted companies may have lower ROE, NPM, ATO and higher LM in delistment preceding years compared with peer companies that stay listed. While there is no direct evidence on how DuPont analysis specifically predicts voluntary delisting decision, however literature review presents many hints towards it. Common characteristics of voluntarily delisted firms are small size, young age, lower growth opportunities, low liquidity, low turnover, undervaluation, high leverage and low profitability. The components of DuPont Analysis can be employed to examine and compare ROEs, NPMs, ATOs and LMs of voluntarily delisted firms with those that remain listed to check if there exists disparity which may help in predicting delisting decisions. Pour and Lasfer (2013) very recently researched into the reasons of voluntary delisting of firms from Alternative Investment Market (AIM) and concluded that along with other things, companies with low profitability delist from AIM. Profitability is measured by ROE and NPM. Boucly et al. (2009); Renneboog et al. (2007); Weir* et al. (2005) have concluded that, along with other things, companies with small size are more likely to delist voluntarily. Size is measured by Assets (Kang, 2017) and salesthe two together make ATO (Asset Turnover ratio calculated as Sales/Assets). Corporations raise equity either to finance their growth or to bring their leverage back into balance (Pagano et al., 1998). Across the Atlantic, the European companies get listed for the purposes of enhancing their bargaining position with banks, leverage reduction, and the organizations that cannot achieve their purpose of rebalancing their leverage by raising equity funds decide to turn private (Boucly et al., 2009). Thus, high or abnormal leverage is also associated in literature with voluntary delisting of firms. Thus, the final component of DuPont analysis namely leverage multiplier (LM) becomes relevant proposition. Pour and Lasfer (2013) reported that voluntarily delisting companies have negative returns, low profitability and high leverage. El Kalak et al. (2018) have recently observed that voluntary delisting is all the more likely when companies revenues fall or expected to fall sharply in the times ahead. They also empirically found that small size and high leverage predict voluntary delistment. From 1998 to 2001, Weir* et al. (2005) researched into the characteristics of delisted firms that opted to go private via LBO. They compared 117 firms with a sample of 362 companies that opted to remain public in the same period and revealed that the delisted firms were smaller, younger, diversified and had lower growth opportunities before them. Thomsen and Vieira (2007) researched into the determinants of 3,577 delistings among 12,612 European companies from 21 different countries between 1995 and 2005. Their findings unfolded that the delisted firms were slow-growing, undervalued and relatively illiquid. More recently, Boucly et al. (2009) examined 830 French firms that delisted via an LBO in 1994-2004 period. By matching the LBO firms with a control group of firms that belong to the same business sector, they found that smaller and undervalued firms were the most likely targets for LBOs. Hensler et al. (1997) compared surviving IPOs Vs. non-surviving IPOs and concluded that age, size and initial return increase survival time. Thus, low profitability, poor efficiency and high leverage are generally associated with voluntary delisting. Therefore, voluntarily delisted companies have lower profitability (ROE, NPM), lower efficiency (ATO) and higher leverage (LM) than average ROE, average NPM, average ATO and average LM of the industries they belong to. Based on extensive literature review, the study proposed following hypotheses:

$\mathrm{H}_{1}$ : Average ROE of voluntarily delisted firms and their respective industries are not equal.

$\mathrm{H}_{0} 1$ : Average ROE of voluntarily delisted firms and their respective industries are equal.

$\mathrm{H}_{2}$ : Average NPM of voluntarily delisted firms and their respective industries are not equal.

$\mathrm{H}_{0}$ 2: Average NPM of voluntarily delisted firms and their respective industries are equal. 
$\mathrm{H}_{3}$ : Average ATO of voluntarily delisted firms and their respective industries are not equal.

$\mathrm{H}_{0} 3$ : Average ATO of voluntarily delisted firms and their respective industries are equal.

$\mathrm{H}_{4}$ : Average LM of voluntarily delisted firms and their respective industries are not equal.

$\mathrm{H}_{0} 4$ : Average LM of voluntarily delisted firms and their respective industries are equal.

\section{Methodology}

Data were obtained from balance sheet analysis reports, compiled and published by the State Bank of Pakistan. Our population is companies delisted voluntarily from Karachi Stock Exchange since the start of 21st Century. Of the 78 companies voluntarily delisted from Karachi Stock Exchange till December 2015, data of 33 companies allowed us to calculate ROE, NPM, ATO and LM. Data of one company delisted in 2016 was also obtained from the same source. Thus, in total, data of 34 companies was available to us for this research. We calculated all the four ratios of DuPont Analysis namely ROE, NPM, ATO and LM for the 6 years preceding the delistment year. These ratios were compared with the same ratios of Industry to see if there existed dissimilarity. There were some difficulties too. In some cases, either the data were not available or calculating the ratios didnt make sense due to peculiar circumstances of the companies. For instance, there were numerous cases where both net profit and equity were negative. Now, calculating ROE in such a case would result in a positive integer, which does not make sense for a company that has negative profitability and negative equity. Many companies could not be included in final data due to these two reasons. Therefore, many such companies were dropped, which otherwise might have helped in proving our hypothesis and only the companies whose data made sense for the purpose of descriptive statistics and comparison with industries were included in final sample.

Finally, 13 companies, whose data set was complete for 6 years preceding and adjacent to delistment year, were chosen. DuPont components were calculated for the delisted companies and their respective industries and compared through t-test in line with Kang (2017). Since the sectors DuPont ratios include the companies listed on Karachi Stock Exchange, therefore the comparison was virtually between voluntarily delisted companies and the companies that stayed listed. The Data of 6 years preceding and adjacent to the delistment year were categorized into 2 groups, T- 6 to T- 4 and T-3 to T-1, where $\mathrm{T}$ is the delistment year. Thus, data in T-6 to T- 4 category were data of $6^{\text {th }}, 5^{\text {th }}$ and $4^{\text {th }}$ year before the delistment year, whereas data in T-3 to $\mathrm{T}-1$ category had data of $3^{r d}, 2^{\text {nd }}$ and $1^{\text {st }}$ year prior to the delistment year. Kang (2017) compared voluntarily delisted and listed firms in two groups too.

\section{Results}

\subsection{Descriptive Statistics}

Table 1 presents means, maximums, minimums and standard deviations of DuPont ratios of voluntarily delisted companies and their respective sectors for the same years. Means of ratios of delisted companies is lower than means of sectors ratios except for the NPM ratio. At the same time, mean of ROE of delisted companies is negative and lower than mean of sectors. However, the ratios had more volatility in companies as indicated by standard deviations.

\subsection{Comparison of Means between Delisted Firms and Sector: $6^{\text {th }}, 5^{\text {th }}$ and $4^{\text {th }}$ Years before Delisting Year}

Table 2 presents results of Model 1, which comprises means of companies and their sectors DuPont ratios calculated for years T- 6 to T-4. The results reveal that means of ATO are almost same, whereas the remaining three means of the companies are lower than their respective sectors means. However, these differences are not statistically different as evidenced by the t-statistics.

\subsection{Comparison of Means between Delisted Firms and Sector: $3^{r d}, 2^{\text {nd }}$, and $1^{\text {st }}$ years before Delisting Year}

Table 3 presents the results of Model 2 which compares the companies means of DuPont Ratios with respective sectors means for the period from T-3 to T-1, where $\mathrm{T}$ is the delistment year of the company. We have divided data into two groups on the expectations that voluntarily delisted companies may emit stronger signals of delistment as they draw close to the delistment year. Results reveal that means of DuPont Ratios for the companies were lower than means of respective sectors except Leverage Multiplier Ratio, which is higher for voluntarily delisted companies. However, these differences are statistically insignificant as indicated by the T-statistic. The results hold that there was no difference of means of ratios between voluntarily delisted firms and their respective sectors.

More interestingly, the two groups had no significant differences with respect to ROE, NPM. ATO and LM and still the voluntarily delisted firms opted to delist from Karachi Stock Exchange. The findings suggest that performance based indicators of ROE, NPM, Asset Management and efficiency indicator of ATO 
Table 1: Descriptive Statistics

\begin{tabular}{lccccc}
\hline DuPont Components & N & Minimum & Maximum & Mean & Std. Deviation \\
\hline ROEC & 78 & -29.00 & 2.98 & -.2510 & 3.36399 \\
NPMC & 78 & -3.34 & 6.70 & .1197 & 1.24228 \\
ATOC & 78 & -.82 & 2.75 & 1.0253 & .65274 \\
LMC & 78 & -323.00 & 332.48 & 1.7961 & 53.32096 \\
ROES & 66 & -.47 & 1.23 & .1820 & .23240 \\
NPMS & 66 & -.18 & .39 & .0536 & .07751 \\
ATOS & 66 & .18 & 3.98 & 1.2077 & .87299 \\
LMS & 66 & 1.27 & 9.79 & 3.0341 & 1.32111 \\
Valid N (list wise) & 66 & & & & \\
\hline
\end{tabular}

Note: $R O E C=$ return on equity of delisted companies, NPMC $=$ net profit margin of delisted companies, ATOC $=$ asset turnover of delisted companies, LMC= leverage multiplier of delisted companies, ROES = return on equity of sector, NPMS = net profit margin of sector, ATOS= asset turnover of sector, LMS=leverage multiplier of sector

Table 2: T-Test for $6^{\text {th }}, 5^{\text {th }}$ and $4^{\text {th }}$ year before delistment year

\begin{tabular}{lccc}
\hline Model 1 & \multicolumn{3}{c}{ (T-6 To T-4) } \\
\hline DuPont Components & Mean of Delisted Firms & Mean of Sector & t-statistics \\
\hline Return on Equity & -0.59 & 0.11 & -0.936 \\
Net Profit Margin & 0.019 & 0.04 & 0.0651 \\
Asset Turnover & 1.11 & 1.10 & 0.017 \\
Leverage Multiplier & -7.74 & 3.16 & -1.29 \\
$\mathrm{~N}$ & 39 & 39 & \\
\hline
\end{tabular}

Note: $T$ is the year in which firm is delisted. For Example, if a company is voluntarily delisted in 2007, its T-6, T-5 and T-4 will be 2001, 2002 and 2003 respectively.

Table 3: T-Test $3^{r d}, 2^{\text {nd }}$ and $1^{\text {st }}$ Year before Delisting

\begin{tabular}{lccc}
\hline Model 2 & \multicolumn{3}{c}{ T-3 To T-1 } \\
\hline DuPont Components & Mean of Delisted Firms & Mean of Sector & t-statistics \\
\hline Return on Equity & 0.1005 & 0.2090 & -1.106 \\
Net Profit Margin & 0.0479 & 0.0684 & -0.132 \\
Asset Turnover & 0.9439 & 1.2073 & -1.434 \\
Leverage Multiplier & 11.3351 & 2.8801 & 0.995 \\
N & 39 & 39 & \\
\hline
\end{tabular}

Note: where $T$ is the year in which firm is delisted. For Example, if a company is voluntarily delisted in 2007, its T-3, T-2 and T-1 will be 2004, 2005 and 2006 respectively. Means of the DuPont ratios of companies were compared with means of their sectors for the same years.

and financing policy (Capital Structure) indicator of LM dont influence the voluntary delistment decision in Pakistan.

\section{Discussion, Conclusion and Im- plications}

Our study was aimed at finding whether the voluntarily delisted firms from the Karachi Stock Exchange since the start of 2001 to the close of 2015 had different financial characteristics than those that stayed listed with respect to DuPont Ratios, on the basis of which the event of voluntary delistment could be predicted. However, results reveal that DuPont Ratios: ROE, NPM, ATO and LM of the voluntarily delisted firms and the ones that stayed listed had no significant differences. Thus, the conclusion drawn from the study is that profitability, asset management (efficiency) and leverage are not the determinants of voluntary delistment of firms. The result stand in agreement with 
Kang (2017), who found that leverage and total asset turnover do not separate the voluntarily delisted firms from listed one in South Korea. She found that profitability of voluntarily delisted firms and listed ones was statistically same in 2nd year (T-2) before delistment. However, in the preceding (T-1) year, voluntarily delisted firms had higher return on assets (ROA), which meant that firms with higher profitability are more likely to go private probably to save their earnings from distribution. Our results stand in contrast to prior research on voluntary delistment decision, which has found that low efficiency, low profitability and higher leverage cause voluntary delistment. For instance, Pour and Lasfer (2013) found that voluntarily delisted firms had significantly different leverage and profitability than those firms which stayed listed. Companies failing to re-balance their leverage go private ie companies with high leverage turn private (Bancel and Mittoo, 2009). Thus, high or abnormal leverage is also associated in literature with voluntary delisting of firms. Pour and Lasfer (2013) reported that voluntarily delisting companies have negative returns, low profitability and high leverage. El Kalak et al. (2018) have recently observed that voluntary delisting is all the more likely when companies revenues fall or expected to fall sharply in the times ahead. They also empirically found that small size and high leverage predict voluntary delistment. However, our study reports that profitability, asset utilization and leverage of the voluntarily delisted firms and the staying firms are very much the same.

Once it is evident that financial performance, efficiency and leverage do not influence voluntary delisting, therefore it can be inferred that companies voluntarily delist due to some other motives such as ownership concentration, agency conflict, ownership structure, regulatory rules \& regulations, costs associated with listing, information asymmetry, conflict between majority \& minority shareholders, investors recognition and analysts coverage etc., which needs to be ascertained in future research. Like decision of going public, it is logical to assume that corporations weigh costs and benefits, and if costs of being listed exceed the benefits, then the normal decision would be to delist from the stock exchange and become a private concern. Going public sharply increases costs. Marosi and Massoud (2007) found that Surbanes-Oxley Act (SOX) and costs to meet the regulatory requirements of stock exchanges as well as regulatory bodies are major factors that have caused many delistings in United States. SOX and free cash flow problem in context of agency cost are extremely important determinants of firms decision to go private (Leuz et al., 2008). Therefore, the first and foremost consideration for the companies to go private is to avoid costs that are associated with listed companiesbe they direct and/or indirect costs. Bharath and Dittmar (2006) opine that since companies undertake cost-benefit analysis at the time of deciding to go public, therefore, it is likely that the same is carried out when they see that costs associated with listings have gone past benefits that emanate from it. These costs and benefits relate to access to financing, agency costs, asymmetric information, and financial visibility. The literature provides evidence that benefits of listings include more liquidity, easier access to financial markets and the likelihood of sharing risk with public investors. However, when companies realize that they are not getting what they had listed for, the ultimate decision is to go private. Why bear cost without having its fruit? Or why bear more cost than benefit?

Mehran and Peristiani (2009) have defined financial visibility as a measure for asymmetric information: it is the capability of a firm to attract sufficient intensity of investor attention and recognition (analyst coverage). Thus analyst coverage is important as it can affect the companies in many ways. Thus it is safe to assume that firms with higher financial visibility are less likely to go private, whereas firms with lower financial visibility are more likely to opt out of the stock market. Another way to evaluate investor attention is to examine the liquidity of the stock and the associated trading expenses. As established by numerous studies and models (Amihud, 2002; Bolton and Von Thadden, 1998; Boot et al., 2006), liquidity of share trading is a key benefit of going public. Resultantly, firms with low stock liquidity are more likely to go private.

For GPTs located in continental Europe, the conflicting parties are large and minority shareholders (Croci and Giudice, 2014). Large shareholders may be desirous of having more benefits that can result from control. In case of BOSO, where the large shareholders (for example, shareholders having $90 \%$ or more voting rights in France) cash out the minority shareholders; the primary conflict is not between shareholders and managers (agency conflict), but between large shareholders and minority shareholders. As suggested by Martinez and Serve (2011), stimuli for large shareholders in deciding to go private may be different for different large shareholders based on firms identity. For a firm largely owned by family members, the incentive to go private may be to have strong unchallenged control and private benefits that are not available to one and all in shareholders list. Families are risk-averse and they prefer to quit the market whenever they find any challenge to their control. This is especially true for smaller and undervalued firms which often become ideal target for the acquisition predators. Family owners may also delist their company to put a ban on the ability of the minority shareholders to sell their shares in the market especially to institutional investors, because as mentioned earlier the primary conflict is between controlling and minority shareholders.

In Anglo-Saxon countries, the principal form of the GPT is LBO, which is often aimed at companies with 
a low ownership concentration. Under such situation, LBO is carried out to avoid agency cost as LBO is regarded instrumental in addressing the agency conflict between managers and shareholders. How an LBO can cause managers interests to align with those of shareholders can be possibly elaborated in two ways (Jensen, 1986). Kaplan $(1989, ?)$ mentions that necessity of realignment of managers and shareholders interests is an important determinant of delisting decision. GPT allows more ownership and hence more control as the delisted and private is now owned by less number of shareholders than when it was a public firm. The profits of the firm are now distributed amongst less number of shareholders and as result, shareholders wealth increases more in a private firm, and this allows shareholders to reward the performance of managers with extra incentives. Thus, the managers may be tempted to work towards shareholders interests for their own benefits.

Another hypothesis that explains reduction in agency conflict as a result of GPT via LBO is free cash flow (FCF) Hypothesis. The high debt that results from substantial borrowing aimed at cashing out shareholders disciplines managers not to waste free cash flow, because they have to undertake debt servicing and they are closely monitored by lenders like banks etc. Free cash flow gives birth to agency conflict between managers and shareholders in public companies, especially in firms with low growth opportunities (Jensen and Meckling, 1976). Therefore, corporations with dual problem of free cash flow and low growth opportunities prefer to go private to address the agency conflict between managers and shareholders. However, we find some mix evidence of this in Literature. Lehn and Poulsen (1989)s findings are that FCF is an important determinant in making decision to go private, whereas Marosi and Massoud (2007) provide evidence that FCF is an important consideration only for firms that generate high cash inflows but at the same time dont have growth opportunities to utilize those high inflows. Kang (2017) points out that international firm voluntarily delist from one stock exchange to register at some other more lucrative stock exchange. She reports that Japanese stock market went up by $105 \%$, Chinese stock markets by $33.6 \%$ and South Korean by merely 5.3\% from December 2011 to December 2014. Thus, market recession serves as determinant of voluntary delisting as well.

\subsection{Limitations and Future Recommenda- tions}

This study found that voluntarily delisted firms in Pakistan had same DuPont Model ratios compared with the sectors they worked in. Therefore, these firms might have got delisted due to some non-performance indicators and variables like ownership concentration, agency conflict, ownership structure, Regulatory rules \& regulations, costs associated with listing, conflict between majority \& minority shareholders, investors recognition and analysts coverage etc., which needs to be ascertained in future research. More research is needed to establish whether voluntarily delisted firms can be distinguished from staying firms on the basis of DuPont model. Our recommendations in this respect for the future researchers are that instead of comparing DuPont ratios, numerators and denominators of the DuPont ratios (net profit, equity, sales and assets) should be compared between voluntarily delisted companies and the companies that stayed listed to avoid problems faced in interpreting ratios calculated from negative numerators and / or denominators.

\section{References}

Amihud, Y. (2002). Illiquidity and stock returns: cross-section and time-series effects. Journal of financial markets, 5(1):3156.

Bancel, F. and Mittoo, U. R. (2009). Why do european firms go public? European Financial Management, 15(4):844-884.

Bharath, S. T. and Dittmar, A. K. (2006). To be or not to be (public). using going private transactions to examine why firms go public. Technical report, Working paper.

Bolton, P. and Von Thadden, E.-L. (1998). Liquidity and control: a dynamic theory of corporate ownership structure. Journal of Institutional and Theoretical Economics (JITE)/Zeitschrift für die gesamte Staatswissenschaft, pages 177-211.

Boot, A. W., Gopalan, R., and Thakor, A. V. (2006). The entrepreneur's choice between private and public ownership. The Journal of Finance, 61(2):803-836.

Boucly, Q., Sraer, D., and Thesmar, D. (2009). Job creating lbos. Technical report, Working Paper, Berkeley University and HEC Paris.

Brau, J. C. (2012). Why do firms go public. The Oxford handbook of entrepreneurial finance, pages 467-494.

Croci, E. and Giudice, A. D. (2014). Delistings, controlling shareholders and firm performance in europe. European Financial Management, 20(2):374-405.

El Kalak, I., Azevedo, A., and Tunaru, R. (2018). Voluntary delisting timing: A real option model and empirical evidence.

Fischer, C. (2000). Why do companies go public? empirical evidence from germany's neuer markt.

Hensler, D. A., Rutherford, R. C., and Springer, T. M. (1997). The survival of initial public offerings in the aftermarket. Journal of Financial Research, 20(1):93-110. 
Jensen, M. C. (1986). Agency costs of free cash flow, corporate finance, and takeovers. The American economic review, 76(2):323-329.

Jensen, M. C. and Meckling, W. H. (1976). Theory of the firm: Managerial behavior, agency costs and ownership structure. Journal of financial economics, 3(4):305-360.

Kang, S. M. (2017). Voluntary delisting in korea: Causes and impact on company performance. Journal of Applied Business Research, 33(2):391.

Kaplan, S. (1989). The effects of management buyouts on operating performance and value. Journal of financial economics, 24(2):217-254.

Lehn, K. and Poulsen, A. (1989). Free cash flow and stockholder gains in going private transactions. The Journal of Finance, 44(3):771-787.

Leuz, C., Triantis, A., and Wang, T. Y. (2008). Why do firms go dark? causes and economic consequences of voluntary sec deregistrations. Journal of Accounting and Economics, 45(23):181-208.

Macey, J., OHara, M., and Pompilio, D. (2008). Down and out in the stock market: the law and economics of the delisting process. The Journal of Law and Economics, 51(4):683-713.

Marosi, A. and Massoud, N. (2007). Why do firms go dark? Journal of Financial and Quantitative Analysis, 42(2):421-442.
Martinez, I. and Serve, S. (2011). The delisting decision: The case of buyout offer with squeeze-out (boso). International Review of Law and Economics, 31(4):228-239.

Mehran, H. and Peristiani, S. (2009). Financial visibility and the decision to go private. The Review of Financial Studies, 23(2):519-547.

Pagano, M., Panetta, F., and Zingales, L. (1998). Why do companies go public? an empirical analysis. The journal of $f_{i-}$ nance, 53(1):27-64.

Pour, E. K. and Lasfer, M. (2013). Why do companies delist voluntarily from the stock market? Journal of Banking $\mathcal{E}$ Finance, 37(12):4850-4860.

Renneboog, L., Simons, T., and Wright, M. (2007). Why do public firms go private in the uk? the impact of private equity investors, incentive realignment and undervaluation. Journal of Corporate Finance, 13(4):591-628.

Ritter, J. R. (1987). The costs of going public. Journal of Financial Economics, 19(2):269-281.

Thomsen, S. and Vieira, F. (2007). Delistings in europe and the costs of governance. Available at SSRN 986603.

Weir*, C., Laing, D., and Wright, M. (2005). Undervaluation, private information, agency costs and the decision to go private. Applied Financial Economics, 15(13):947-961. 